\title{
GENETIC DISSECTION OF PROTEIN AND GLUTEN CONTENTS IN WHEAT (TRITICUM AESTIVUM L.) UNDER NORMAL AND DROUGHT CONDITIONS
}

\author{
AHMED, H. G. M.-D. ${ }^{1,2,4^{*}}-$ KASHIF, M. ${ }^{2}-$ SAJJAD, M. ${ }^{3}-$ ZENG, Y.-W. ${ }^{4 *}$ \\ ${ }^{1}$ University of Central Punjab, Department of Botany, Punjab Group of Colleges, Bahawalpur \\ 63100, Pakistan \\ ${ }^{2}$ Department of Plant Breeding and Genetics, University of Agriculture, Faisalabad, Punjab \\ 38000, Pakistan. \\ ${ }^{3}$ Department of Biosciences, COMSATS University Islamabad (CUI), Park Road, Islamabad \\ 45550, Pakistan \\ ${ }^{4}$ Biotechnology and Germplasm Resources Institute, Yunnan Academy of Agricultural Sciences, \\ Kunming 650205, China \\ *Corresponding authors \\ e-mail: ahmedbreeder@gmail.com; zengyw1967@126.com
}

(Received $30^{\text {th }}$ Dec 2019; accepted $9^{\text {th }}$ Jul 2020)

\begin{abstract}
Breeding drought resistant wheat is very important for sustainable food production. In future research, each new cross from breeder will involve the modification of genome-wide gene networks that control the expression of drought and yield, especially the dynamics of change in complex gene families involved in drought adaptation. Declining water resources as a result of extreme use of water for irrigation and climate change pose a severe threat to food security. It is needed to divulge and manipulate the genetic potential of wheat (Triticum aestivum L.) germplasm to adapt to scarce water resources with higher/sustainable yield potential. In this regard, drought-tolerant and drought-susceptible wheat genotypes were manipulated in line (10) $\times$ tester (5) mating design in the department of PBG-UAF Pakistan to understand the genetic mechanism and effect of drought tolerance on wheat yield and quality attributes like protein and gluten contents under normal and drought conditions. It was imperative to breed wheat genotypes that withstand in drought environments having maximum yield and protein contents. The significant specific combining ability (SCA) provided the prominent non-additive genetic mechanism in the inheritance of yield and quality traits in wheat for the studied germplasm. Gene action based screening revealed that the line 9493 (L1), tester 9508 (T1) and their hybrid (L1 $\times$ T1) were ideal genetic resources to breed against drought resistance for quality and yield attributes. Therefore, hybrid breeding will be rewarding and the selection practice for superior individual plants should be delayed to advanced generations like $F_{4}$ and $F_{5}$. The superior genotype 9493 and hybrid (cross) 9493 (L1) $\times 9508$ (T1) can be combined to develop new promising and improved hybrids/varieties for quality and yield contributing attributes under drought conditions to fulfill the wheat demand and sustainable food security. Keywords: breeding, gene action, additive, germplasm, food security, genotypes
\end{abstract}

\section{Introduction}

Current wheat (Triticum aestivum) having three A, B and D homeologous genomes, has been evolved through a series of natural crossing and the effect of polyploidy $(2 n=6 x=42$, AABBDD allohexaploid) (Ahmed et al., 2017a). In the evolutionary pathway of modern wheat, allopolyploidization occurred in two phases; in first step T. urartu (diploid) hybridized with Aegilops speltoides (wild grass) that resulted into tetraploid T. Turgidum and in the 2nd step, tetraploid AABB, $2 \mathrm{n}=4 \mathrm{x}=28$ crossed with diploid goat grass A. tauschii having the 
genome DD $2 \mathrm{n}=2 \mathrm{x}=14$ which produced (hexaploid = AABBDD) modern wheat (Förster et al., 2012).

The evolution of large seeded non-shattering modern wheat cultivars from small-seeded wild cultivars with natural grain dispersal and cross pollination modified the seed shape and size. Increase in grain size might have started during the early stages of wheat evolution when cultivation of the plant was started (Peña-Bautista, 2002). Seed size is a quantitative polygenic trait which is influenced by many genes that significantly contribute to increase or decrease seed size (Peng et al., 2011).

Generally, wheat grain comprises protein (8-17\%), carbohydrates (60-80\%) (mainly starch), minerals (1.5-2\%), fats (1.5-2\%), crude fibers (2.2\%), vitamins (B complex and E) and all essential amino acids except tryptophan, methionine and lysine. Gluten is a protein complex that accounts for 75 to $85 \%$ of the total protein in wheat (Fuller, 2007). Due to its nutritional worth and preference, people like to utilize wheat in daily food in the form of bread, chapati, crackers, etc. Wheat grain has distinct physical and chemical parameters of seed protein. Understanding the inheritance mechanism of wheat grain and quality traits is necessary for attaining the best genotypes on this aspect (Ali et al., 2013). Selection of best performing parental genotypes and their cross combinations are necessary for creating the desirable wheat varieties (Akram et al., 2011). The overall crop production all over the world has to be significantly increased day by day to feed a rising population, but existing production trends are not enough to meet this increasing requirement (Zeeshan et al., 2013).

Water deficit decreases the yield so it is assumed that 17 to $70 \%$ losses in the yield are due to water deficiency. Wheat yield reduced from 50 to $90 \%$ of their irrigated potential in the developing countries by water deficit conditions (Ali et al., 2013). Wheat plant suffers severe response to water deficit stress at tillering, jointing, booting, anthesis and filling stages. Tillering is a very important stage at which plant develops tillers, primodia of spike, spikelets, and flowers. Water deficit stress at this stage can cause a $46 \%$ decrease in total yield (Minhas et al., 2014). For breeding water deficit tolerance in wheat crop, it is important to know the mechanism and behavior of plant under drought environments. To stand against the water shortage conditions plant has different morphological, physiological, biochemical, anatomical and molecular developments (Noorka and Teixeira da Silva, 2014).

Genetic purity analysis for hybrid testing is compulsory to certify the hybrid seed. Hybrid testing and confirmation is essential for commercial purpose and for the production of pure hybrids. Conventionally, genetic purity examined on the basis of phenotypic data are tested in field trials and compared with improved cultivated genotypes the term used as 'Grow-Out Test' (GOT). The limitations of this test are higher cost, time consumption, requirement of large area for testing, and influence of environmental factors (Wu et al., 2010). Combining ability analysis is an effective genetic evaluation tool and therefore has been commonly implemented in plant breeding to access the performance of genotypes in hybrid/cross combinations (Kumar et al., 2011). Different types of gene actions have been estimated from combining ability variances which indicate the expression of quality, yield and yield contributing parameters. Additionally, comprehensive information about the relationship between line per se and hybrid potential is necessary to improve wheat breeding programs (Longin et al., 2012).

Regardless the small amount of hybrid vigor in self-pollinated crops, like in wheat the agronomic worth of their hybrids seemed to be encouraging. In China, Rice hybrid had a yield benefit of $20-30 \%$ over the commercial cultivars. In private sectors, wheat hybrids have been successfully developed in India and European countries (Cheng et al., 2007). 
Previously, different types of gene actions had been reported from combining ability variances which influence the expression of yield and its contributing parameters in bread wheat (Bibi et al., 2013). Yield character is a polygenic in nature which is widely affected due to environmental variations. In wheat breeding schemes the direct selection for yield and yield contributing characters may give false results especially against drought environments. Therefore, the genetic effectiveness of indirect selection is valuable than direct screening for yield and yield contributing traits in wheat breeding programs (Akram et al., 2011; Zeeshan et al., 2013).

Keeping all above in view, the experiments were planned to generate information from, combining ability studies, gene action analysis under normal and drought conditions. The information derived from these studies would be very useful for wheat breeders to exploit the new genetic potential in wheat genotypes for developing drought tolerant, better protein contents and high yielding wheat varieties for sustainable food security.

\section{Materials and methods}

The proposed research was conducted to assess the genetic mechanism of some quality and yield contributing traits in wheat under normal and drought stress conditions.

\section{Line $\times$ tester analysis (hybridization)}

The field experiment for line $\times$ tester analysis was carried out in the research area of Plant Breeding and Genetics (PBG) department, University of Agriculture, Faisalabad, Pakistan $\left(\right.$ LATITUDE $=31-44^{\prime} \mathrm{N}$ and ALTITUDE $\left.=184.4 \mathrm{~m}\right)$. The tested ten drought tolerant genotypes namely, 9493 (L1), 9618 (L2), 9797 (L3), 9930 (L4), BWL812 (L5), DPW621 (L6), 10111 (L7), 10115 (L8), 10117 (L9) and Chakwal-86 (L10) were used as a female (line) parent and five drought susceptible wheat genotypes 9508 (T1), Millat-11 (T2), Ufaq-2002 (T3), Moomal-2002 (T4) and BARS-09 (T5) were used as male (tester) parents (Ahmed et al., 2019). These genotypes were crossed under line $(\mathrm{L} 10) \times$ tester (T5) mating design during the wheat growing seasons 2016-17.

In wheat crop anthesis starts from the center of the spike (inflorescence) and then proceeds in both directions. Hence, for emasculation purpose the suitable lateral florets were kept in the middle of the inflorescence and left over unwanted florets were detached with the help of a pair of scissors and pointed forceps. Then the small florets were supported with thumb and forefinger and 1/3 upper part of each floret was removed with a pair of scissors. The immature anthers (3) in each floret were carefully detached by using fine pointed forceps, avoiding damage to the ovary and prevent ovary from selfpollination. Glycine bags were used to cover entire spikes immediately after completion of emasculation, to minimize the chance of pollination. Male flowers with mature anthers were excluded from the female lines to avoid any chance of self-pollination. On the very next day early in the morning emasculated spike which were covered under glycine bags were pollinated by using fresh pollen from the desired male parent by hand. After completion of artificial pollination spikes of female plants were again tightly covered with their respective bags till seed setting and to avoid the contamination with other undesired pollens. These cultivars/lines were hybridized in (10) lines $\times(5)$ testers mating fashion. For each parental line 50 spikes were emasculated and pollinated with desired testers, so total 500 spikes were emasculated in this experiment. In each spike average 15 seed sets and 150 crossed seed obtained for each line with their respective testers like L1 $\times \mathrm{T} 1$. At 
maturity, crossed seeds from all crosses were collected manually in separate envelops which were orderly arranged for each and every cross.

\section{Evaluation of breeding material}

Total fifty $F_{1}$ seeds along with their 15 parents genotypes were sown on November 15, 2017 in two experimental conditions (non-stressed and drought stressed experiments) in randomized complete block design (RCBD) with three replications. Each genotype was sown through maintaining plant-to-plant distance fifteen centimeters and rows-to-row distance was $30 \mathrm{~cm}$. Two seeds of each genotype were dibbled/hole and one healthy seedling was reserved after germination by thinning. To abate the border effect lines of non-experimental material were sown at the border of the experiment. In normal experiment irrigations were applied at three critical stages i.e. (1) tillering (35 Days after sowing, DAS), (2) the booting stage (85 DAS) and (3) the milking stage (112 DAS) (Noorka and Teixeira da Silva, 2014). Drought stress was applied at tillering stage by upholding (missing) the irrigation treatment. One set of genotypes was irrigated at all the three-critical stages, while the other set of the same wheat genotypes was kept under drought stress. Fertilizer were applied at the rate of 46 $\mathrm{kg}$ nitrogen, $34 \mathrm{~kg}$ phosphorus and $25 \mathrm{~kg}$ potash per acre All regular agronomic applications like fertilizer, hoeing, weeding, etc. were implemented equivalently in both experiments to lessen the experimental faults (Ahmed et al., 2018).

\section{Measurement of quality and yield components}

At maturity, when wheat plants were fully established, data were collected of 10 plants from each replication for following some quality and yield contributing characters of fifty crosses and their fifteen parents under normal and water deficient conditions. Harvesting was done on 8-15 April, 2018. The studied traits were observed using the following methods. The flag leaf area was calculated according to (Muller, 1991) i.e., (maximum length $\times$ maximum breadth) $\times 0.74$. Then average area of flag leaf was calculated, relative water contents (RWC) and cell membrane thermo-stability (CMT) were measured using the standard methods described by Dhanda et al. (1998) and Blum and Ebercon (1981), respectively. Number of grain per spike (GPS) was counted from the spike of mother shoot of each randomly selected plant and 1000-grain weight (TGW) was measured with electric balance from the produce each pre- selected plant. For grain yield per plant (GYP) ten randomly selected plants were harvested at maturity and threshed grains were weighed using electric balance. The yield of mother tillers was also added to the produce. Then average yield was calculated as produce was divided by number of plants. Grain quality traits like, grain protein contents (GPC) and gluten contents (GC) investigated by Kernalyser (NIR spectroscopy, ISO17025 certified and $18 \mathrm{~mm}$ spacer), which included grain protein percentage (\%) and grain gluten percentage (\%) (Liana et al., 2012; Maria et al., 2013). The data of these quality characters were measured via Near-Infrared Radiation (NIR) procedure by running the wheat genotype samples.

\section{Biometrical analysis of line $\times$ tester}

Data recorded at different stages of plants for all traits, under normal and drought stress conditions, were subjected to analysis of variance (Steel, 1997) to sort out significant differences among studied germplasm. The traits which showed, significant genotypic differences, were further analyzed for the determination of other genetic 
parameters. Studied characters were also subjected to line $\times$ tester analysis (Kempthorne, 1957) to calculate the combining ability, genetic components and proportional contribution under normal and drought conditions.

\section{Results and discussion}

\section{Line $\times$ tester analysis of variances}

Mean square values from line $\times$ tester analysis of variances were considered to observe the significant variation in parents and their crosses for quality and yield contributing indices under normal and water deficit conditions (Table 1). Highly significant differences were scored between female parents and crosses for all studied traits in the present research under normal and water deficit conditions. Under both conditions highly significant differences were scored between parents for flag leaf area, relative water contents, cell membrane thermo-stability, grains per spike, and protein contents while significant variation was observed only under normal conditions for 1000-grain weight. The GYP and GC between parents were showed non-significant variation under both conditions.

Table 1. Mean squares values from line $\times$ tester analysis of variances

\begin{tabular}{|c|c|c|c|c|c|c|c|c|c|c|c|c|c|c|c|c|c|}
\hline \multirow{2}{*}{ Sov } & & \multicolumn{2}{|c|}{ FLA } & \multicolumn{2}{|c|}{ RWC } & \multicolumn{2}{|c|}{ CMT } & \multicolumn{2}{|c|}{ GPS } & \multicolumn{2}{|c|}{ TGW } & \multicolumn{2}{|c|}{ GYP } & \multicolumn{2}{|c|}{ GPC } & \multicolumn{2}{|c|}{$\mathrm{BC}$} \\
\hline & & $\mathbf{N}$ & D & $\mathbf{N}$ & D & & 1 & & & & & & & $\mathbf{N}$ & D & 18 & D \\
\hline $\mathbf{K}$ & 2 & 55.6 & & & & & & & & & r & & & & & & \\
\hline G & 64 & & & $191^{* * *}$ & & & & & & $105.21^{* *}$ & $81.51^{* *}$ & $5^{* * *}$ & $5^{* *}$ & $2.40^{* *}$ & $2.53^{* * *}$ & $9^{* *}$ & 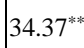 \\
\hline P & 4 & & 70 & $155^{* *}$ & $159.2^{* *}$ & & ** & ** & $74.41^{* *}$ & $10.17^{* *}$ & 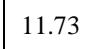 & & & $2.01^{* * *}$ & $2.01^{* * *}$ & & \\
\hline $\mathrm{C}$ & 49 & *** & $40.1^{* * *}$ & $205^{* *}$ & *** & 3 & ** & & $100.14^{* *}$ & $130.45^{* *}$ & $100.16^{* *}$ & $6^{*}$ & *** & $2.42^{* *}$ & $2.69^{* *}$ & $48.31^{* *}$ & pi \\
\hline $\mathrm{v} C$ & 1 & & $27.4^{* * *}$ & 0. & & & & & & & & & & $7.12^{* *}$ & 2.44 & *** & \\
\hline $\mathrm{L}$ & 9 & * & $635^{* *}$ & $423^{* *}$ & ** & $J^{1}$ & $* *$ & ${ }^{* * *}$ & 32 & $* * *$ & 1** & $*^{* * *}$ & $3^{* *}$ & $5.28^{* *}$ & $5.14^{* *}$ & ${ }^{* * *}$ & \\
\hline $\mathrm{T}$ & 4 & & $28.9^{* * *}$ & $118^{* *}$ & & & 31. & *** & $47.14^{* *}$ & $40.36^{* *}$ & $45.11^{* *}$ & $45.01^{* *}$ & $22.60^{* *}$ & $1.06^{* *}$ & 1.15 & $84.34^{* *}$ & 98.76 \\
\hline$\times \mathrm{T}$ & 36 & $4^{* *}$ & $35.5^{*}$ & $160^{* *}$ & $* *$ & 118.8 & 65.3 & $56.54^{* *}$ & $48.67^{* *}$ & 67.8 & $44.31^{* *}$ & 72.7 & & 1.85 & $2.24^{* *}$ & $*$ & 33.5 \\
\hline E & 128 & & 3.8 & 21.3 & 9.8 & 53 & 11.2 & & 15. & 2.2 & 13.61 & 4.7 & 0.6 & 0.86 & 1.1 & 12.99 & 14.0 \\
\hline
\end{tabular}

$\mathrm{SOV}=$ sources of Variations, DF, degree of Freedom, FLA = flag leaf area, RWC = relative water content, CMT = cell membrane thermostability, GPS = grain per spike, TGW = thousand grain weight, GYP = grain yield per plant, GPC $=$ grain protein content, $\mathrm{GC}=$ gluten content. $\mathrm{D}=$ drought stressed, $\mathrm{N}=$ normal (non-stressed), $\mathrm{L}=$ line (female parent), $\mathrm{T}=$ tester $($ male parent). $\mathrm{R}=$ replication, $\mathrm{G}=$ genotype, $\mathrm{P}=$ parent, $\mathrm{C}=$ cross, $\mathrm{L}=$ line, $\mathrm{T}=$ tester, $\mathrm{E}=$ environment, $*=$ significant $(\mathrm{P}<0.05), * *=$ highly significant $(\mathrm{P}<0.01)$

Evaluation of the testers showed highly significant differences was for all examined characters in non-stressed and drought stressed environments except GPC which were non-significant under water deficit condition. Parent versus crosses ( $\mathrm{P}$ vs $\mathrm{C}$ ) exhibited non-significant results for RWC (normal and drought) and GPC (drought) while the variation in remaining traits were highly significant under normal and water deficit conditions. Considering the $\mathrm{L} \times \mathrm{T}$ interaction, highly significant variability existed for all tested traits under both conditions except GYP (drought) and GPC (normal) which showed non- significant behavior.

Highly significant, variability was described by wheat breeders (Kalhoro et al., 2015) for GPS and GYP. Significant results were reported (Ramani et al., 2017) for relative water contents, protein and gluten contents. Earlier scientist reported (Minhas et al., 2014) the significant results of FLA and GPS between parents and their hybrids which were in accordance with the present findings. The line $\times$ tester analysis of variances (ANOVA) showed that the genetic variability existed between parents and their crosses/hybrids for 
some quality and yield contributing indices in wheat under normal and water deficit conditions. So, this germplasm could be used in future for wheat hybrid breeding schemes to develop the drought tolerant and high yielding wheat varieties.

\section{Flag leaf area $\left(\mathrm{cm}^{2}\right)$}

Flag leaf has perilous role in wheat, because its photosynthates to be stored in seed. So, it has direct relationship with grain yield. Under normal and water deficit conditions maximum flag leaf area (FLA) $39.67 \mathrm{~cm}^{2}$ and $28.67 \mathrm{~cm}^{2}$ respectively was scored for Line1 (L1). Among the male parents, highest mean values for FLA were $36.19 \mathrm{~cm}^{2}$ and $31.24 \mathrm{~cm}^{2}$ for Tester1 (T1) under both conditions, respectively (Table 2). Highly significant positive general combining ability (GCA) effects were revealed by the genotype L1 possessing the values 3.31 and 3.51 under normal and water deficit conditions, respectively. Among testers, the genotypes T1 had maximum positive GCA effects with the values 1.28 and 1.48 under normal and water deficit conditions, respectively (Table 3). Similar findings have been reported by wheat breeders (Kumar et al., 2011) for this trait in wheat crop using the same methodology as in current study.

Table 2. The parental genotypes with highest mean values for various traits under study

\begin{tabular}{c|c|c}
\hline Characters & Normal & Drought \\
\hline Flag leaf area & L1 (39.67), L2 (37.83), T1 (36.19) & L1 (28.67), L2 (26.83), T1 (31.24) \\
Relative water contents & L1 (80.32), L2 (78.32), T1 (63.32) & L1 (69.16), L2 (67.32), L3 (58.19) \\
Cell membrane thermo-stability & L1 (58.69), L3 (57.69), T1 (50.90) & L1 (56.6), L3 (55.6), T1 (48.60) \\
Grain per spike & L1 (65.63), L2 (64.34), T1 (56.34) & L1 (48.55), L2 (47.34), T1 (40.34) \\
Thousand grain weight & L1 (52.54), L9 (51.56), T2 (48.98) & L1 (34.31), L6 (34.31), T2 (32.98) \\
Grain yield per plant & L1 (33.95), L2 (33.8), T1 (27.00) & L1 (21.89), L3 (21.79), T1 (18.00) \\
Grain protein contents & L10 (12.92), T4 (12.83), T4 (12.83) & L1 (14.97), T1 (14.95), T5 (14.95) \\
Gluten contents & L10 (28), L2 (25.97), T4 (22.67) & L1 (29.93), L2 (27.9), T5 (24.9) \\
\hline
\end{tabular}

$\mathrm{L}=$ line (female parent), $\mathrm{T}=$ tester (male parent)

Among crosses, FLA mean values exhibited in L1 $\times \mathrm{T} 1$ as $43.28 \mathrm{~cm}^{2}$ and $32.17 \mathrm{~cm}^{2}$ under normal and water deficit conditions, respectively. The estimation of SCA effects for the flag leaf area was revealed that cross combinations $\mathrm{L} 1 \times \mathrm{T} 1$ possessed maximum positive SCA effects with the values 6.26 and 6.07 under normal and water deficit conditions, respectively (Table 4.). Significant GCA and SCA effects were observed earlier by many wheat scientists (Akram et al., 2011; Zeeshan et al., 2013) for this trait. Significant and positive hybrid vigor is beneficial for this character accordingly desirable for breeding program (Longin et al., 2012) but negative SCA were also found by earlier wheat breeders (Minhas et al., 2014). Flag leaf area (FLA) of wheat plant is an important character and directly influence on yield because greater area enables to produce photosynthates in higher amount, which have to translocate in seed to increase their yield.

\section{Relative water content (\%)}

Soil moisture deficit is a major adverse factor in arid and semi-arid zones, causing lower leaf water potential, leading to reduced turgor and, ultimately, lower crop productivity. Under normal and water deficit conditions maximum relative water content $80.32 \%$ and $69.16 \%$ was scored in L1. Maximum mean values of relative 
water content $63.32 \%$ (normal) and $58.19 \%$ (drought) for $\mathrm{T} 1$ (Table 2). The magnitude of GCA effects between female parents, the highest positive GCA effects were revealed by the genotype L1 possessing the values 9.45 (normal) and 7.64 (drought). Among testers, the genotypes T3 (normal) and T1 (drought) had maximum positive GCA effects with the values 1.78 and 1.90 respectively as shown in Table 3. Similar research has also been confirmed by whet breeders (Ashfaq et al., 2016) using line $\times$ tester analysis.

Table 3. The parental genotypes with highest general combining ability (GCA) effects

\begin{tabular}{c|c|c|c}
\hline Characters & & Normal & Drought \\
\hline \multirow{2}{*}{ Flag leaf area } & $\mathrm{L}$ & $\mathrm{L} 1(3.31), \mathrm{L} 2(2.91), \mathrm{L} 10(1.11)$ & $\mathrm{L} 1(3.51), \mathrm{L} 2(3.11), \mathrm{L} 10(1.31)$ \\
& $\mathrm{T}$ & $\mathrm{T} 1(1.28), \mathrm{T} 2(0.87)$ & $\mathrm{T} 1(1.48), \mathrm{T} 2(0.42)$ \\
\hline Relative water & $\mathrm{L}$ & $\mathrm{L} 1(9.45), \mathrm{L} 7(5.04), \mathrm{L} 2(4.83)$ & $\mathrm{L} 1(7.64), \mathrm{L} 7(5.55), \mathrm{L} 2(2.54)$ \\
contents & $\mathrm{T}$ & $\mathrm{T} 3(1.78), \mathrm{T} 2(1.03)$ & $\mathrm{T} 1(1.90), \mathrm{T} 2(0.59)$ \\
\hline Cell membrane & $\mathrm{L}$ & $\mathrm{L} 1(3.65), \mathrm{L} 2(3.54), \mathrm{L} 10(2.22)$ & $\mathrm{L} 1(2.94), \mathrm{L} 10(0.96), \mathrm{L} 7(0.73)$ \\
thermo-stability & $\mathrm{T}$ & $\mathrm{T} 1(2.72), \mathrm{T} 3(2.46)$ & $\mathrm{T} 1(3.65), \mathrm{T} 3(1.63)$ \\
\hline \multirow{2}{*}{ Grain per spike } & $\mathrm{L}$ & $\mathrm{L} 1(7.95), \mathrm{L} 6(6.96), \mathrm{L} 5(5.62)$ & $\mathrm{L} 1(6.89), \mathrm{L} 6(5.75), \mathrm{L} 5(5.7)$ \\
\hline Thousand grain & $\mathrm{T}$ & $\mathrm{T} 1(1.66), \mathrm{T} 2(1.24)$ & $\mathrm{T} 1(1.91), \mathrm{T} 2(0.42)$ \\
weight & $\mathrm{T}$ & $\mathrm{L} 1(9.37), \mathrm{L} 3(4.58), \mathrm{L} 10(4.11)$ & $\mathrm{L} 1(5.03), \mathrm{L} 3(4.77), \mathrm{L} 10(4.17)$ \\
Grain yield per plant & $\mathrm{L}$ & $\mathrm{L} 1(4.47), \mathrm{L} 2(4.26), \mathrm{L} 10(3.54)$ & $\mathrm{L} 1(3.74), \mathrm{L} 2(2.86), \mathrm{L} 10(2.15)$ \\
& $\mathrm{T}$ & $\mathrm{T} 1(1.67), \mathrm{T} 2(0.48)$ & $\mathrm{T} 1(1.04), \mathrm{T} 4(0.43)$ \\
\hline \multirow{2}{*}{ Grain protein contents } & $\mathrm{L}$ & $\mathrm{L} 10(1.46), \mathrm{L} 9(0.33), \mathrm{L} 6(0)$ & $\mathrm{L} 1(1.34), \mathrm{L} 9(0.22), \mathrm{L} 4(0.20)$ \\
& $\mathrm{T}$ & $\mathrm{T} 3(0.16), \mathrm{T} 2(0.13)$ & $\mathrm{T} 1(0.17), \mathrm{T} 2(0.06)$ \\
\hline \multirow{2}{*}{ Gluten contents } & $\mathrm{L}$ & $\mathrm{L} 10(3.79), \mathrm{L} 5(1.66), \mathrm{L} 6(1.60)$ & $\mathrm{L} 1(2.27), \mathrm{L} 10(2.09), \mathrm{L} 7(1.27)$ \\
& $\mathrm{T}$ & $\mathrm{T} 4(1.83), \mathrm{T} 3(1.52)$ & $\mathrm{T} 3(1.78), \mathrm{T} 4(1.08)$ \\
\hline
\end{tabular}

$\mathrm{L}=$ line (female parent), $\mathrm{T}=$ tester (male parent)

Among crosses RWC mean values varied from $82.73 \%$ to $77.30 \%$ for cross $\mathrm{L} 1 \times \mathrm{T} 1$ in non-stressed and drought stressed environments respectively and the remaining 5 superior crosses also presented in Table 4. The magnitudes of SCA effects for RWC revealed that cross combinations $\mathrm{L} 1 \times \mathrm{T} 1$ possessed maximum positive SCA effects with the values 13.55 and 15.26 in non-stressed and drought stressed environments respectively (Table 4). Similar results were scored by many plant scientists (Ashfaq et al., 2016; Ramani et al., 2017) for SCA effects in wheat crop against relative water contents trait. This physiological characteristic has great importance when screening wheat genotypes for drought tolerance. Plant scientists showed that wheat cultivars having high RWC are more resistant to drought stress.

\section{Cell membrane thermo-stability (\%)}

Cell membrane thermo-stability (CMT) is a useful parameter for the rapid evaluation of drought response in wheat breeding. This is the only adaptive and positive response beneficial to the plant under drought conditions. The line L1 had maximum cell membrane thermo-stability $58.69 \%$ (normal) and $56.60 \%$ (drought) while the tester, T1 had maximum values $50.90 \%$ (normal) and 48.60 (drought) as displayed in Table 2. Among female parents L1 possessed maximum positive GCA effects with the values 
3.65 and 2.94 in non-stressed and drought stressed environments respectively. Among testers, maximum positive GCA effects were possessed by T1 with the values 2.72 and 3.65 under non-stress and stress conditions respectively (Table 3). These findings are similar with the previous results reported in wheat crop under normal and drought stress conditions for this trait (Longin et al., 2012; Ramani et al., 2017). In the current study for CMT, the genotypes showing the best performance were classified as droughttolerant, while the low performing genotypes were identified as drought-susceptible.

The CMT mean values were $64.03 \%$ (normal) and $60.70 \%$ (drought) for the crosses L $6 \times \mathrm{T} 3$ and L1 $\times \mathrm{T} 1$ as mentioned in Table 4 . The magnitudes of SCA effects revealed that cross combinations L1 $\times \mathrm{T} 1$ had positive SCA effects with the values 10.69 and 6.09 under both conditions, respectively (Table 4). Previously some scientists (Longin et al., 2012) inspected significant GCA and SCA effects in hexaploid wheat using line $\times$ tester mating designs and support the current study results. While some wheat breeders (Punia et al., 2011) reported the highest positive GCA effects as compared to SCA effects for CMT and their results contradicted with current study. The relative water content and cell membrane thermo-stability were also considered important selection criteria for wheat against drought stress.

\section{Grain per spike}

Under normal conditions grains per spike mean values varied from 57.34 to 65.63 for lines, in tester ranged from 49.63 to 56.34 . The line L1 had maximum number of grain per spike (GPS) 65.63 and 48.55 in non-stressed and drought stressed environments, respectively. The tester, T1 had maximum values 56.34 and 40.34 under both conditions, respectively as displayed in Table 2. Among lines, the genotypes L1 possessed maximum positive GCA effects with the values 7.95 under non-stress and 6.89 under stress. Among testers, maximum positive GCA effects were possessed by T1 with the values 1.66 for normal and 1.91 for drought (Table 3). These findings match with the results of Kumar et al. (2011) and their colleagues using line $\times$ tester mating design in wheat crop for this trait.

Among crosses, grains per spike having maximum mean values 66.34 (normal) and 49.32 (drought) for L1 $\times \mathrm{T} 1$ as mentioned in Table 4. The magnitudes of SCA effects revealed that cross combinations $\mathrm{L} 1 \times \mathrm{T} 1$ and highly significant and positive SCA effects with the values 8.24 and 7.71 in non-stressed and drought stressed environments, respectively, as presented in Table 4. Significance SCA effects for grain per spike in wheat was estimated by wheat breeders (Kalhoro et al., 2015) which are similar with our findings. Both significant GCA and SCA effects also reported (Bibi et al., 2013; Ahmed et al., 2017b) in non-stressed and drought stressed environments and were in accordance with current findings.

\section{0-grain weight (g)}

Under normal conditions maximum 1000 grain weight (TGW) $52.54 \mathrm{~g}$ was scored in L1. Maximum mean values of TGW were $48.98 \mathrm{~g}$ for T2 between male parents (Table 2). The mean values of TGW under drought conditions the line L1 had maximum TGW $34.31 \mathrm{~g}$ and tester T2 (32.98) as shown in Table 2. Among female parents L1 possessed maximum positive GCA affects with the values 9.37 and 5.03 while, between the testers maximum positive GCA effects were possessed by $\mathrm{T} 2$ and $\mathrm{T} 1$ with the values 1.52 and 1.06 in non-stressed and drought stressed environments respectively as displayed in 
Table 3. These findings are in line with the findings of wheat scientists (Fellahi et al., 2013; Liu et al., 2016) for this attribute in wheat crop under normal and drought stress conditions.

Table 4. Mean and specific combining ability (SCA) values of superior crosses (hybrids) in non-stressed and drought stressed environments

\begin{tabular}{|c|c|c|c|c|}
\hline \multirow{2}{*}{ Characters } & \multicolumn{2}{|c|}{ Mean } & \multicolumn{2}{|c|}{ SCA } \\
\hline & Normal & Drought & Normal & Drought \\
\hline \multirow{5}{*}{ Flag leaf area } & $\mathrm{L} 1 \times \mathrm{T} 1(43.28)$ & $\mathrm{L} 1 \times \mathrm{T} 1(32.17)$ & $\mathrm{L} 1 \times \mathrm{T} 1(6.26)$ & $\mathrm{L} 1 \times \mathrm{T} 1(6.07)$ \\
\hline & $\mathrm{L} 1 \times \mathrm{T} 2(42.19)$ & $\mathrm{L} 1 \times \mathrm{T} 2(31.21)$ & $\mathrm{L} 9 \times \mathrm{T} 4(5.58)$ & $\mathrm{L} 10 \times \mathrm{T} 4(6.04)$ \\
\hline & $\mathrm{L} 10 \times \mathrm{T} 4(40.5)$ & $\mathrm{L} 10 \times \mathrm{T} 4(29.5)$ & $\mathrm{L} 6 \times \mathrm{T} 5$ (5.12) & $\mathrm{L} 9 \times \mathrm{T} 4(5.36)$ \\
\hline & $\mathrm{L} 2 \times \mathrm{T} 2(40.22)$ & $\mathrm{L} 2 \times \mathrm{T} 3(29.45)$ & $\mathrm{L} 1 \times \mathrm{T} 2(4.92)$ & $\mathrm{L} 6 \times \mathrm{T} 5(4.78)$ \\
\hline & $\mathrm{L} 2 \times \mathrm{T} 3(40.21)$ & $\mathrm{L} 2 \times \mathrm{T} 2(29.22)$ & $\mathrm{L} 10 \times \mathrm{T} 4(4.33)$ & $\mathrm{L} 1 \times \mathrm{T} 2(4.72)$ \\
\hline \multirow{5}{*}{$\begin{array}{l}\text { Relative water } \\
\text { contents }\end{array}$} & $\mathrm{L} 1 \times \mathrm{T} 1(82.73)$ & $\mathrm{L} 1 \times \mathrm{T} 1(77.30)$ & $\mathrm{L} 1 \times \mathrm{T} 1(13.55)$ & $\mathrm{L} 1 \times \mathrm{T} 1(15.26)$ \\
\hline & $\mathrm{L} 1 \times \mathrm{T} 3(82.32)$ & $\mathrm{L} 3 \times \mathrm{T} 5(69.32)$ & $\mathrm{L} 4 \times \mathrm{T} 2(10.03)$ & $\mathrm{L} 9 \times \mathrm{T} 1(8.68)$ \\
\hline & $\mathrm{L} 3 \times \mathrm{T} 5(80.32)$ & $\mathrm{L} 7 \times \mathrm{T} 3(68.67)$ & $\mathrm{L} 10 \times \mathrm{T} 4(9.56)$ & $\mathrm{L} 6 \times \mathrm{T} 5(8.18)$ \\
\hline & $\mathrm{L} 2 \times \mathrm{T} 5(79.66)$ & $\mathrm{L} 1 \times \mathrm{T} 3(67.55)$ & $\mathrm{L} 9 \times \mathrm{T} 1(7.95)$ & $\mathrm{L} 4 \times \mathrm{T} 2(7.19)$ \\
\hline & $\mathrm{L} 1 \times \mathrm{T} 2(79.32)$ & $\mathrm{L} 8 \times \mathrm{T} 1(67.32)$ & $\mathrm{L} 8 \times \mathrm{T} 1(7.84)$ & $\mathrm{L} 5 \times \mathrm{T} 2(6.99)$ \\
\hline \multirow{5}{*}{$\begin{array}{l}\text { Cell membrane } \\
\text { thermo-stability }\end{array}$} & L6 × T3 (64.70) & $\mathrm{L} 1 \times \mathrm{T} 1(60.70)$ & $\mathrm{L} 1 \times \mathrm{T} 1(10.69)$ & $\mathrm{L} 1 \times \mathrm{T} 1(6.09)$ \\
\hline & $\mathrm{L} 7 \times \mathrm{T} 3(64.03)$ & $\mathrm{L} 4 \times \mathrm{T} 3(60.05)$ & $\mathrm{L} 6 \times \mathrm{T} 5(9.89)$ & $\mathrm{L} 9 \times \mathrm{T} 5(6.07)$ \\
\hline & $\mathrm{L} 1 \times \mathrm{T} 1(62.80)$ & L6 × T3 (59.95) & $\mathrm{L} 9 \times \mathrm{T} 4(9.27)$ & $\mathrm{L} 8 \times \mathrm{T} 2(5.22)$ \\
\hline & $\mathrm{L} 3 \times \mathrm{T} 1(62.69)$ & $\mathrm{L} 9 \times \mathrm{T} 3(59.75)$ & $\mathrm{L} 9 \times \mathrm{T} 5(7.28)$ & $\mathrm{L} 8 \times \mathrm{T} 1(5.11)$ \\
\hline & $\mathrm{L} 7 \times \mathrm{T} 1(62.69)$ & $\mathrm{L} 8 \times \mathrm{T} 1(59.60)$ & $\mathrm{L} 2 \times \mathrm{T} 4(7.65)$ & $\mathrm{L} 2 \times \mathrm{T} 5(4.85)$ \\
\hline \multirow{5}{*}{ Grain per spike } & $\mathrm{L} 1 \times \mathrm{T} 1(66.34)$ & $\mathrm{L} 1 \times \mathrm{T} 1(49.32)$ & $\mathrm{L} 1 \times \mathrm{T} 1(8.24)$ & $\mathrm{L} 1 \times \mathrm{T} 1(7.71)$ \\
\hline & L5 × T4 (66.04) & $\mathrm{L} 5 \times \mathrm{T} 4(49.04)$ & $\mathrm{L} 4 \times \mathrm{T} 4(6.51)$ & $\mathrm{L} 2 \times \mathrm{T} 1(5.38)$ \\
\hline & $\mathrm{L} 6 \times \mathrm{T} 2(66.04)$ & L6 × T1 (48.34) & $\mathrm{L} 2 \times \mathrm{T} 1(4.56)$ & $\mathrm{L} 4 \times \mathrm{T} 5(5.15)$ \\
\hline & $\mathrm{L} 6 \times \mathrm{T} 1(65.34)$ & L5 × T3 (47.34) & $\mathrm{L} 2 \times \mathrm{T} 3(4.56)$ & $\mathrm{L} 10 \times \mathrm{T} 2(5.06)$ \\
\hline & $\mathrm{L} 5 \times \mathrm{T} 3(64.34)$ & $\mathrm{L} 6 \times \mathrm{T} 2(47.29)$ & $\mathrm{L} 7 \times \mathrm{T} 1(4.08)$ & $\mathrm{L} 4 \times \mathrm{T} 4(3.78)$ \\
\hline \multirow{5}{*}{$\begin{array}{l}\text { Thousand grain } \\
\text { weight }\end{array}$} & $\mathrm{L} 1 \times \mathrm{T} 2(58.54)$ & $\mathrm{L} 1 \times \mathrm{T} 1(38.54)$ & $\mathrm{L} 1 \times \mathrm{T} 2(8.78)$ & $\mathrm{L} 1 \times \mathrm{T} 1(7.83)$ \\
\hline & $\mathrm{L} 1 \times \mathrm{T} 4(58.54)$ & $\mathrm{L} 10 \times \mathrm{T} 3(38.54)$ & $\mathrm{L} 7 \times \mathrm{T} 5(8.04)$ & $\mathrm{L} 7 \times \mathrm{T} 5(6.67)$ \\
\hline & $\mathrm{L} 1 \times \mathrm{T} 1(56.55)$ & $\mathrm{L} 3 \times \mathrm{T} 4(38.54)$ & $\mathrm{L} 3 \times \mathrm{T} 3(6.61)$ & $\mathrm{L} 10 \times \mathrm{T} 1(5.63)$ \\
\hline & $\mathrm{L} 1 \times \mathrm{T} 3(56.54)$ & $\mathrm{L} 10 \times \mathrm{T} 1(38.23)$ & $\mathrm{L} 4 \times \mathrm{T} 1(5.84)$ & ------ \\
\hline & $\mathrm{L} 3 \times \mathrm{T} 4(55.54)$ & $\mathrm{L} 7 \times \mathrm{T} 2(38.19)$ & $\mathrm{L} 10 \times \mathrm{T} 1(5.59)$ & ----- \\
\hline \multirow{5}{*}{$\begin{array}{l}\text { Grain yield per } \\
\text { plant }\end{array}$} & $\mathrm{L} 1 \times \mathrm{T} 1(36.91)$ & $\mathrm{L} 1 \times \mathrm{T} 1(25.91)$ & $\mathrm{L} 1 \times \mathrm{T} 1(6.93)$ & $\mathrm{L} 1 \times \mathrm{T} 1(6.90)$ \\
\hline & $\mathrm{L} 1 \times$ T $2(33.39)$ & $\mathrm{L} 3 \times \mathrm{T} 2(23.35)$ & $\mathrm{L} 6 \times \mathrm{T} 4(6.18)$ & $\mathrm{L} 9 \times \mathrm{T} 2(6.5)$ \\
\hline & $\mathrm{L} 10 \times \mathrm{T} 2(32.39)$ & $\mathrm{L} 1 \times \mathrm{T} 3(22.00)$ & $\mathrm{L} 2 \times \mathrm{T} 5(6.16)$ & $\mathrm{L} 3 \times \mathrm{T} 2(6.09)$ \\
\hline & $\mathrm{L} 3 \times \mathrm{T} 2(31.00)$ & $\mathrm{L} 2 \times \mathrm{T} 5(22.00)$ & $\mathrm{L} 3 \times \mathrm{T} 1(6.12)$ & $\mathrm{L} 2 \times \mathrm{T} 5(6.09)$ \\
\hline & $\mathrm{L} 6 \times \mathrm{T} 5(30.06)$ & $\mathrm{L} 2 \times \mathrm{T} 1(22.00)$ & $\mathrm{L} 6 \times \mathrm{T} 5(6.08)$ & $\mathrm{L} 5 \times \mathrm{T} 3(4.94)$ \\
\hline \multirow{5}{*}{$\begin{array}{l}\text { Grain protein } \\
\text { contents }\end{array}$} & $\mathrm{L} 10 \times \mathrm{T} 5(14.06)$ & $\mathrm{L} 1 \times \mathrm{T} 1(14.97)$ & $\mathrm{L} 1 \times \mathrm{T} 3(2.22)$ & $\mathrm{L} 1 \times \mathrm{T} 1(1.95)$ \\
\hline & $\mathrm{L} 9 \times \mathrm{T} 2(14.01)$ & $\mathrm{L} 10 \times \mathrm{T} 5(14.95)$ & $\mathrm{L} 7 \times \mathrm{T} 3(1.96)$ & $\mathrm{L} 2 \times \mathrm{T} 1(1.72)$ \\
\hline & $\mathrm{L} 1 \times \mathrm{T} 5(13.98)$ & $\mathrm{L} 6 \times \mathrm{T} 2(14.92)$ & $\mathrm{L} 9 \times \mathrm{T} 2(1.91)$ & $\mathrm{L} 5 \times \mathrm{T} 2(1.34)$ \\
\hline & $\mathrm{L} 7 \times \mathrm{T} 2(13.97)$ & $\mathrm{L} 1 \times \mathrm{T} 4(14.90)$ & $\mathrm{L} 5 \times \mathrm{T} 2(1.65)$ & $\mathrm{L} 1 \times \mathrm{T} 5(1.26)$ \\
\hline & $\mathrm{L} 2 \times \mathrm{T} 1(13.95)$ & $\mathrm{L} 8 \times \mathrm{T} 3(14.89)$ & $\mathrm{L} 2 \times \mathrm{T} 1(1.03)$ & ------ \\
\hline \multirow{5}{*}{ Gluten contents } & $\mathrm{L} 1 \times \mathrm{T} 1(28.97)$ & $\mathrm{L} 5 \times \mathrm{T} 4(31.60)$ & $\mathrm{L} 1 \times \mathrm{T} 1(6.75)$ & $\mathrm{L} 1 \times \mathrm{T} 1(4.86)$ \\
\hline & L5 × T4 (28.67) & L5× T1 (30.95) & $\mathrm{L} 9 \times \mathrm{T} 4(5.11)$ & $\mathrm{L} 9 \times \mathrm{T} 4(4.38)$ \\
\hline & L5 × T5 (28.67) & $\mathrm{L} 8 \times \mathrm{T} 4(30.90)$ & $\mathrm{L} 2 \times \mathrm{T} 2(4.65)$ & $\mathrm{L} 5 \times \mathrm{T} 4(4.32)$ \\
\hline & $\mathrm{L} 7 \times \mathrm{T} 4(28.67)$ & $\mathrm{L} 8 \times \mathrm{T} 3(30.60)$ & $\mathrm{L} 1 \times \mathrm{T} 2(4.55)$ & ----- \\
\hline & $\mathrm{L} 8 \times \mathrm{T} 3(28.67)$ & $\mathrm{L} 7 \times \mathrm{T} 3(30.31)$ & ------ & ------ \\
\hline
\end{tabular}


Among crosses, the highest mean values $58.54 \mathrm{~g}$ and $38.54 \mathrm{~g}$ for L1 $\times \mathrm{T} 1$ in nonstressed and drought stressed environments as shown in Table 4. The magnitudes of SCA effects for 1000-grain weight revealed that cross combinations L1 $\times$ T2 and L1 $\times$ $\mathrm{T} 1$ in non-stressed and drought stressed environments possessed maximum positive SCA effects with the values 8.78 and 7.83 respectively (Table 4). Similar findings were scored (Fellahi et al., 2013; Ahmed et al., 2017b) for this character from combining ability analysis in wheat crop under normal and drought stress conditions.

\section{Grain yield per plant (g)}

In non-stressed and drought stressed environments maximum grain yield per plant (GYP) $33.95 \mathrm{~g}$ and $21.89 \mathrm{~g}$ were scored in L1 respectively. Maximum mean values for GYP $27.00 \mathrm{~g}$ and $18.00 \mathrm{~g}$ under both conditions respectively (Table 2). The magnitude of GCA effects between female parents revealed by the genotypes L1 and L5 possessing the highest positive values 4.47 and 3.74 while the T1 showed the highest positive GCA effects with the values 1.67 and 1.04 in non-stressed and drought stressed environments respectively (Table 3).

Among crosses, GYP showing highest mean values $36.91 \mathrm{~g}$ (normal) and $25.91 \mathrm{~g}$ (drought) for cross $\mathrm{L} 1 \times \mathrm{T} 1$ as shown in Table 4 . The magnitudes of SCA effects revealed that cross combinations $\mathrm{L} 1 \times \mathrm{T} 1$ had positive and highly significant SCA effects with the values 6.93 and 6.90 under both conditions respectively as presented in Table 4. Grain yield per plant had significant GCA and SCA effects described earlier from combining ability analysis in wheat crop (Fellahi et al., 2013; Kalhoro et al., 2015) under normal and drought stress conditions while, some scientists (Kumar et al., 2011; Ahmed et al., 2018) inspected the higher positive GCA effects than SCA effects for this character which showed the contradiction with the current results. Only significant SCA effects for GYP that were exhibited the contribution of dominant genes action. Grain yield is polygenic characters which is affected environmental conditions. Significant genetic variability between wheat germplasm for yield contributing traits was found by Minhas et al. (2014), Ashfaq et al. (2016) and Ahmed et al. (2019).

\section{Grain protein contents (\%)}

Under normal condition maximum grain protein contents (GPC) $12.92 \%$ was scored in L10 while, maximum mean values for GPC was $12.83 \%$ for T4. Under drought conditions, the line L1 had maximum GPC $14.97 \%$, the GPC maximum value 14.95 for T5 as shown in Table 2. The highest positive GCA effects between female parents were revealed by the genotypes L10 and L1 possessing the values 1.46 and 1.34 while, the genotype T3 (3.79) and T1 (0.17) in non-stressed and drought stressed environments respectively. These results are supported by the earlier findings (Guzmán et al., 2016) in wheat genotypes from combining ability analysis using line $\times$ tester mating design.

The cross combination L10 $\times$ T5 had maximum values 14.1 under normal conditions while, 14.9 for $\mathrm{L} 1 \times \mathrm{T} 1$ under drought environments. The magnitudes of SCA effects of GPC revealed that cross combinations L1 $\times \mathrm{T} 3$ (normal) and L1 $\times \mathrm{T} 1$ (drought) were possessed maximum positive SCA effects with the values 2.22 and 1.95 respectively (Table 4). It was perceived (Maich et al., 2017) that genetic distance was significantly and positively linked with SCA effects for grain protein contents in wheat crop under normal and drought stress conditions. From combining ability study only significant SCA effects were observed for protein contents in wheat grain. Both GCA and SCA 
effects were also recorded (Kraljević-Balalić et al., 1982) and exhibited significance in the inheritance of grain protein contents in wheat grain under normal and drought stress conditions.

\section{Gluten contents $(\%)$}

Under normal condition maximum gluten contents (GC) values $28.00 \%$ was scored in L10 while $22.67 \%$ for T4 (Table 2). Under drought conditions line L1 had maximum GC $29.93 \%$ and maximum value $24.90 \%$ for T5 as shown in Table 2. Among lines, the genotypes L10 and L1 possessed maximum positive GCA effects with the values 3.79 and 2.27 while the genotypes having maximum GCA effects T4 and T3 with the values 1.83 and 1.78 in non-stressed and drought stressed environments, respectively (Table 3). These results are similar with the study by several wheat scientists (Peng et al., 2011; Guzmán et al., 2016) in wheat genotypes from combining ability analysis using line $\times$ tester mating design under normal drought stress conditions.

The cross combinations $\mathrm{L} 1 \times \mathrm{T} 1$ and $\mathrm{L} 5 \times \mathrm{T} 4$ had maximum values $28.97 \%$ and $31.60 \%$ in non-stressed and drought stressed environments, respectively. The magnitudes of SCA effects revealed that cross combinations L1 $\times \mathrm{T} 1$ had positive SCA effects with the values 6.75 and 4.86 in non-stressed and drought stressed environments respectively as presented in Table 4. Gluten contents had significant GCA and SCA effects examined by wheat breeders (Arya et al., 2017) which were in line with the current study. It is the ability of an individual to transfer the best character to its cross/hybrid and designates the significant breeding value of individuals in the creation of the best hybrid (Kempthorne, 1957). It is an influential analysis to differentiate the best and poor combiners for selecting suitable parental genotypes for a specific trait in wheat breeding scheme and also delivers the evidence about the types of gene action controlling the yield and yield related characters.

\section{Gene action}

Variance due to GCA $=\sigma 2 \mathrm{GCA}$ is helpful for determining the hybrid potential using the GCA effects values of their parental lines. Trial based research (Fellahi et al., 2013; Kalhoro et al., 2015) exhibited that GCA variances are more prominent than SCA variances, assortment due to GCA effects of the tester (male parent) is a favorable method, but choice of lines (female parent) with maximum GCA in crosses is essential to exploit the yield in the production of hybrid seed (Longin et al., 2012).

If general combining ability variance is greater than specific combing ability variance then selection will be done in the earlier generations due to the presence of additive types of gene action. If the values of SCA variances are higher from GCA variances, then dominant genes are supposed to be responsible for controlling the character and hybrid breeding can be proposed and selection are not useful in earlier generation. In present study the GCA:SCA ratio was less than one which indicating the preponderance of dominance types of genetic effects under both conditions in studied characters. In this case hybrid breeding may be recommended and it would be greater effective. The SCA variance was greater than GCA variance for number of tillers per plant and cell membrane thermos-stability suggesting that dominance types of genetic effects was prominent in the inheritance for these characters. Similar results have been observed by many wheat scientists (Liu et al., 2016; Longin et al., 2012) in wheat crop using line $\times$ tester mating design under normal and drought stress conditions. 
Due to non-additive genetic mechanism governing most of the yield relating traits, selection of the superior plants would have to be practiced with great care while handling the plant-material in segregating generations. Observing the proportional contributions of female parents, male parents and their hybrids to the total variance for studied traits (Table 5), lines were more prominent for the characters like flag leaf area, relative water contents, cell membrane thermo-stability, grain yield/plant, GPC and GC under normal irrigation, indicating a predominant maternal influence. Tester contribution was very low proportion, while the line $\times$ tester interaction contributed predominantly to1000-grain weight under both conditions Various scientists have suggested only dominance genetic effects (Kumar et al., 2011; Bibi et al., 2013) and some reported (Kalhoro et al., 2015) the additive genetic effects for yield and yield related traits in wheat under both conditions for improving the selection efficiency. Both types of genetic effects in yield contributing characters of wheat were suggested (Akram et al., 2011) from combining ability analysis under drought stress environments.

Table 5. Estimates of genetic components and proportional contributions of lines and tester

\begin{tabular}{|c|c|c|c|c|c|c|c|c|c|}
\hline \multirow{2}{*}{ Traits } & \multirow{2}{*}{ Environment } & \multicolumn{5}{|c|}{ Gene action } & \multicolumn{3}{|c|}{$\begin{array}{l}\text { Proportional } \\
\text { contribution }\end{array}$} \\
\hline & & $\sigma^{2} \mathrm{GCA}$ & $\sigma^{2} \mathrm{SCA}$ & $\begin{array}{l}\sigma^{2} \mathbf{A}=\sigma^{2} \\
\mathbf{G C A} * 2\end{array}$ & $\begin{array}{c}\sigma^{2} \mathrm{D}=\sigma^{2} \\
\mathrm{SCA}\end{array}$ & $\tilde{\sigma}^{2} \mathbf{A} / \mathbf{\sigma}^{2} \mathbf{D}$ & $\mathbf{L}$ & $\mathbf{T}$ & $L \times T$ \\
\hline \multirow{2}{*}{ FLA } & $\mathrm{N}$ & 0.04 & 11.73 & 0.08 & 11.73 & 0.01 & 26 & 6 & 68 \\
\hline & $\mathrm{D}$ & 0.06 & 10.53 & 0.12 & 10.53 & 0.01 & 29 & 6 & 65 \\
\hline \multirow{2}{*}{ RWC } & $\mathrm{N}$ & 0.59 & 46.42 & 1.18 & 46.42 & 0.03 & 38 & 5 & 57 \\
\hline & $\mathrm{D}$ & 1.00 & 24 & 2 & 24 & 0.08 & 42 & 6 & 52 \\
\hline \multirow{2}{*}{ CMT } & $\mathrm{N}$ & 36.3 & 0.31 & 72.68 & 0.31 & 234.4 & 16 & 23 & 61 \\
\hline & $\mathrm{D}$ & 18.0 & 0.22 & 36.06 & 0.22 & 163.9 & 10 & 31 & 59 \\
\hline \multirow{2}{*}{ GPS } & $\mathrm{N}$ & 0.95 & 15.94 & 1.9 & 15.94 & 0.12 & 64 & 4 & 32 \\
\hline & $\mathrm{D}$ & 0.68 & 11.14 & 1.36 & 11.14 & 0.12 & 60 & 4 & 36 \\
\hline \multirow{2}{*}{ TGW } & $\mathrm{N}$ & 0.83 & 21.89 & 1.66 & 21.89 & 0.08 & 59 & 3 & 38 \\
\hline & $\mathrm{D}$ & 0.74 & 10.23 & 1.48 & 10.23 & 0.14 & 64 & 4 & 33 \\
\hline \multirow{2}{*}{ GYP } & $\mathrm{N}$ & 0.45 & 22.67 & 0.9 & 22.67 & 0.04 & 47 & 3 & 50 \\
\hline & $\mathrm{D}$ & 0.31 & 15 & 0.62 & 15 & 0.04 & 46 & 2 & 52 \\
\hline \multirow{2}{*}{ GPC } & $\mathrm{N}$ & 0.01 & 0.61 & 0.02 & 0.61 & 0.03 & 35 & 3 & 62 \\
\hline & $\mathrm{D}$ & 0.01 & 0.38 & 0.02 & 0.38 & 0.05 & 35 & 3 & 61 \\
\hline \multirow{2}{*}{ GC } & $\mathrm{N}$ & 0.16 & 7.33 & 0.32 & 7.33 & 0.04 & 32 & 13 & 55 \\
\hline & $\mathrm{D}$ & 0.07 & 6.51 & 0.14 & 6.51 & 0.02 & 16 & 21 & 64 \\
\hline
\end{tabular}

FLA = flag leaf area, $\mathrm{RWC}=$ relative water content, $\mathrm{CMT}=$ cell membrane thermostability, GPS $=$ grain per spike, $\mathrm{TGW}=$ thousand grain weight, $\mathrm{GYP}=$ grain yield per plant, $\mathrm{GPC}=$ grain protein content, $\mathrm{GC}=$ gluten content. $\mathrm{L}=$ line (female parent), $\mathrm{T}=$ tester (male parent)

Breeding with drought resistance of wheat is very important for sustainable food production. In the future research, each new cross from breeder involves the modification of genome-wide gene networks (Appels et al., 2018) that control the expression of drought and yield, especially the dynamics of change in complex gene families involved in drought adaptation. 


\section{Conclusion}

Among parents, the line 9493 (L1) and the tester 9508 (T1) proved to be the best general combiners for most of the yield contributing indices under both conditions due to higher GCA effects. Among the hybrids L1 $\times$ T1 was the ideal specific combiner for most of the quality and yield related traits under both conditions. GCA variances were observed less than SCA variances suggesting that a dominance genetic effect was prominent in the inheritance for examined indices. Hence, the selection practice for superior individual plants should be delayed to next generations like $\mathrm{F}_{4}$ or $\mathrm{F}_{5}$. The superior genotypes and their cross combinations showed promising one for exploitation in wheat breeding program to develop best quality and high yielding wheat genotypes against drought stress conditions to fulfill the needs of wheat and sustainable food security.

Acknowledgement. This work was funded by the China Agriculture Research System (CARS-05-01A-04).

\section{REFERENCES}

[1] Ahmed, H. G. M.-D., Khan, A. S., Khan, S. H., Kashif, M. (2017a): Genome wide allelic pattern and genetic diversity of spring wheat genotypes through SSR markers. International Journal of Agriculture and Biology 19: 1559-1565.

[2] Ahmed, H. G. M.-D., Khan, A. S., Kashif, M., Khan, S. H. (2017b): Genetic mechanism of leaf venation and stomatal traits for breeding drought tolerant lines in wheat. Bangladesh Journal of Botany 46: 35-41.

[3] Ahmed, H. G. M.-D., Khan, A. S., Kashif, M., Khan, S. (2018): Genetic analysis of yield and physical traits of spring wheat grain. - Journal of the National Science Foundation of Sri Lanka 46.

[4] Ahmed, H. G. M.-D., Sajjad, M., Li, M., Azmat, M. A., Rizwan, M., Maqsood, R. H., Khan, S. H. (2019): Selection criteria for drought-tolerant bread wheat genotypes at seedling stage. - Sustainability 11: 2584.

[5] Akram, Z., Ajmal, S. U., Khan, K. S., Qureshi, R., Zubair, M. (2011): Combining ability estimates of some yield and quality related traits in spring wheat (Triticum aestivum L.). - Pak. j. bot 43: 221-231.

[6] Ali, A., Ali, N., Ullah, N., Ullah, F., Adnan, M., Ahmed, Z. (2013): Effect of drought stress on the physiology and yield of the Pakistani wheat germplasms. - International Journal of Advancements in Research \& Technology 2: 419.430-2013.

[7] Appels, R., Eversole, K., Feuillet, C., Keller, B., Rogers, J., Stein, N., Pozniak, C. J., Choulet, F., Distelfeld, A., Poland, J. (2018): Shifting the limits in wheat research and breeding using a fully annotated reference genome. - Science 361: eaar7191.

[8] Arya, V. K., Singh, J., Kumar, L., Kumar, R., Kumar, P., Chand, P. (2017): Genetic variability and diversity analysis for yield and its components in wheat (Triticum aestivum L.). - Indian Journal of Agricultural Research 51.

[9] Ashfaq, W., Ul-Allah, S., Kashif, M., Sattar, A., Nabi, H. G. (2016): Genetic variability study among wheat genotypes under normal and drought conditions. - J. Glob. Innov. Agric. Soc. Sci 4: 111-116.

[10] Bibi, R., Hussain, S. B., Khan, A. S., Raza, I. (2013): Assessment of combining ability in bread wheat by using line $\mathrm{x}$ tester analysis under moisture stress conditions. - Pak. J. Agric. Sci 50: 111-115.

[11] Blum, A., Ebercon, A. (1981): Cell membrane stability as a measure of drought and heat tolerance in wheat. - Crop Sci 21: 43-47. 
[12] Cheng, S.-H., Zhuang, J.-Y., Fan, Y.-Y., Du, J.-H., Cao, L.-Y. (2007): Progress in research and development on hybrid rice: a super-domesticate in China. - Annals of botany 100: 959-966.

[13] Dhanda, S., Sethi, G. (1998): Inheritance of excised-leaf water loss and relative water content in bread wheat (Triticum aestivum). - Euphytica 104: 39-47.

[14] Fellahi, Z. E. A., Hannachi, A., Bouzerzour, H., Boutekrabt, A. (2013): Line $\times$ tester mating design analysis for grain yield and yield related traits in bread wheat (Triticum aestivum L.). - International Journal of Agronomy 2013.

[15] Förster, S., Schumann, E., Weber, W. E., Pillen, K. (2012): Discrimination of alleles and copy numbers at the $\mathrm{Q}$ locus in hexaploid wheat using quantitative pyrosequencing. Euphytica 186: 207-218.

[16] Fuller, D. Q. (2007): Contrasting patterns in crop domestication and domestication rates: recent archaeobotanical insights from the Old World. - Annals of botany 100: 903-924.

[17] Guzmán, C., Autrique, J. E., Mondal, S., Singh, R. P., Govindan, V., Morales-Dorantes, A., Posadas-Romano, G., Crossa, J., Ammar, K., Peña, R. J. (2016): Response to drought and heat stress on wheat quality, with special emphasis on bread-making quality, in durum wheat. - Field Crops Research 186: 157-165.

[18] Kalhoro, F. A., Rajpar, A. A., Kalhoro, S. A., Mahar, A., Ali, A., Otho, S. A., Soomro, R. N., Ali, F., Baloch, Z. A. (2015): Heterosis and combing ability in F1 population of hexaploid wheat (Triticum Aestivum L.). - American Journal of Plant Sciences 6: 1011.

[19] Kempthorne, O. 1957. An Introduction to Genetic Statistics. - John Wiley and Sons, Inc., New York.

[20] Kraljević-Balalić, M., Štajner, D., Gašić, O. (1982): Inheritance of grain proteins in wheat. - Theoretical and Applied Genetics 63: 121-124.

[21] Kumar, P., Yadava, R., Gollen, B., Kumar, S., Verma, R. K., Yadav, S. (2011): Nutritional contents and medicinal properties of wheat: a review. - Life Sciences and Medicine Research 22: 1-10.

[22] Liana, A., Alda, S., Fora, C., Diana, M., Gogoasa, I., Bordean, D., Cârciu, G., Cristea, T. (2012): Climatic conditions influence on the variation of quality indicators of some Romanian and foreign winter wheat cultivars. - Journal of Horticulture, Forestry and Biotechnology 16: 68-72.

[23] Liu, B., Asseng, S., Liu, L., Tang, L., Cao, W., Zhu, Y. (2016): Testing the responses of four wheat crop models to heat stress at anthesis and grain filling. - Global Change Biology 22: 1890-1903.

[24] Longin, C. F. H., Mühleisen, J., Maurer, H. P., Zhang, H., Gowda, M., Reif, J. C. (2012): Hybrid breeding in autogamous cereals. - Theoretical and Applied Genetics 125: 10871096.

[25] Maich, R. H., Steffolani, M. E., Di Rienzo, J. A., Leon, A. E. (2017): Association between grain yield, grain quality and morpho-physiological traits along ten cycles of recurrent selection in bread wheat (Triticum aestivum L.). - Cereal Research Communications 45: 146-153.

[26] Maria, A. L., Lavinia, C. L., Fora, C., Alda, S., Gogoasa, I., Despina, B. (2013): Researches regarding some winter wheat cultivars behavior under pedo-climatic conditions of Timis County. - Journal of Horticulture, Forestry and Biotechnology 17: 87-90.

[27] Minhas, N. M., Ajmal, S. U., Ahmed, Z. I., Munir, M. (2014): Genetic analysis for grain quality traits in Pakistani wheat varieties. - Pak J Bot 46: 1409-1413.

[28] Muller, J. (1991): Determining leaf surface area by means of linear measurements in wheat and triticale (brief report). - Archiv Fuchtungsforsch 21: 121-123.

[29] Noorka, I. R., Teixeira da Silva, J. A. (2014): Physical and morphological markers for adaptation of drought-tolerant wheat to arid environments. - Pakistan Journal of Agricultural Sciences 51. 
[30] Peña-Bautista, R. 2002. Wheat for bread and other foods. Bread wheat: improvement and production. - http://www.fao.org/3/y4011e0w.htm.

[31] Peng, J. H., Sun, D., Nevo, E. (2011): Domestication evolution, genetics and genomics in wheat. - Molecular Breeding 28: 281.

[32] Punia, S., Shah, A. M., Ranwha, B. R. (2011): Genetic analysis for high temperature tolerance in bread wheat. - African Crop Science Journal 19: 149-163.

[33] Ramani, H., Mandavia, M., Dave, R., Bambharolia, R., Silungwe, H., Garaniya, N. (2017): Biochemical and physiological constituents and their correlation in wheat (Triticum aestivum L.) genotypes under high temperature at different development stages. - International Journal of Plant Physiology and Biochemistry 9: 1-8.

[34] Steel, R. G. D., Torrie, J. H., Dickey, D. A. (1997): Principles and Procedures of Statistics: A Biometrical Approach. - McGraw Hill Book Company, New York.

[35] Wu, M., Jia, X., Tian, L., Lv, B. (2010): Rapid and reliable purity identification of F 1 hybrids of Maize (Zea may L.) using SSR markers. - Maize Genomics and Genetics 2010(1).

[36] Zeeshan, M., Arshad, W., Ali, S. (2013): Genetic diversity and trait association among some yield parameters of wheat elite lines genotypes under rainfed conditions. - J Renewable Agri 1: 23-26. 